\title{
Interpretacje
}

\section{„Serdecznie dziękujemy za przybliżenie nam historii Polaków ratujących żydów". Recepcja polskich muzeów "Sprawiedliwych" w świetle wpisów w księgach gości - Apteka pod Orłem, Willa Żabińskich, Muzeum Ulmów}

Zofia Wóycicka

TEKSTY DRUGIE 2020, NR 4, S. 188-212

DOI: 10.18318/td.2020.4.11 | ORCID: 0000-0002-9461-2387

$\mathbf{W}$ iosną 2016 roku, po uroczystym otwarciu w Markowej Muzeum Polaków ratujących Żydów podczas drugiej wojny światowej im. Rodziny Ulmów, na łamach prasy polskiej i zagranicznej rozgorzała debata dotycząca samego Muzeum oraz politycznej instrumentalizacji tematu „Sprawiedliwych” w Polsce. Głos w dyskusji zabrało wielu historyków i dziennikarzy, przedstawiciele Instytut Pamięci Narodowej oraz Yad Vashem'.

1 Patrz m.in.: O. Adered Polish museum honoring Poles who waved Jews arouses controversy, "Haaretz Online" 22.03.2016; J. Croitoru War die heldenhafte Familie Ulma etwa typisch?, "Frankfurter Allgemeine Zeitung Online" 9.04.2016, www.faz.net/aktuell/feuilleton/judenrettung-in-polen-heldenhaftigkeit-einer-ganzennation-14162281.htm (25.04.2018); Ł. Kamiński Finger weg von unseren Helden!, "Frankfurter Allgemeine Zeitung" 15.04.2016; IPN odpowiada GW po ataku na Muzeum Ulmów: «Historia jest o wiele bardziej skomplikowana niż wydaje się autorom tekstu», "WPolityce.pl" 10.12.2016, http://wpolityce.pl/historia/318823-tylko-u-nas-ipn-odpowiadagw-po-ataku-na-muzeum-ulmow-historia-jest-o-wiele-bardziejskomplikowana-niz-wydaje-sie-autorom-tekstu (14.08.2020); G. Górny Demaskujemy kłamstwo w "Gazecie Wyborczej" na temat Polaków
Zofia Wóycicka - dr,

historyczka, kuratorka muzealna, pracuje w Niemieckim Instytucie Historycznym w Warszawie. Ostatnio opublikowała: Cultural Diplomacy in War Museums. The Case of the German-Russian Museum Berlin-Karlshorst (z Davidem Clarkiem) History \& Memory. Vol. 31, No. 2, 2019 oraz Global Patterns, Local Interpretations: New Polish Museums Dedicated to the Rescue of jews during the Holocaust "Holocaust Studies: A Journal of Culture and History", Vol 25, 2019 - Issue 3. 
Najostrzejszą krytykę muzeum w Markowej sformułowało jednak dwóch historyków związanych z Centrum Badań nad Zagładą Żydów, Jan Grabowski i Dariusz Libionka. W serii artykułów publikowanych na łamach „Gazety Wyborczej” i „Zagłady Żydów. Studiów i Materiałów” zarzucali oni twórcom muzeum przemilczanie lokalnego kontekstu historii Ulmów oraz fałszowanie obrazu stosunków polsko-żydowskich podczas II wojny światowej². Powoływali się przy tym na źródła historyczne, które wskazują, że podczas gdy niektórzy mieszkańcy Markowej i okolic ukrywali Żydów, inni tropili ich i mordowali. „Niestety - jak pisali obaj historycy - ofiara Sprawiedliwych Polaków - ludzi, którzy bezinteresownie ratowali Żydów - jest dziś cynicznie używana do kończenia dyskusji o mniej chwalebnych postawach polskiego

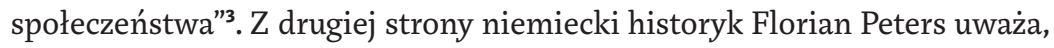
że mimo wielu wad, muzeum w Markowej niesie istotny przekaz, a mianowicie, że Polacy nie byli tylko biernymi, bezwolnymi świadkami Zagłady, ale że ich postawa, obojętność, pomoc, wrogość czy udział w zbrodni miały istotny wpływ na losy prześladowanych. „Chociaż - jak pisze Peters - muzeum w Markowej nie konfrontuje swoich gości otwarcie z tymi problemami, to przynajmniej w sposób pośredni przekazuje myśl, że postawa lokalnych społeczności i indywidualne wybory ludzkie nie były bez znaczenia"4 Wyraża

rzekomo mordujących Żydów, „WPolityce.pl” 20.12.2016, http://wpolityce.pl/historia/320314-demaskujemy-klamstwo-w-gazecie-wyborczej-na-temat-polakow-rzekomo-mordujacych-zy dow (11.02.2017); O. Adered "Orgy of Murder»: The Poles who «hunter»/ews and turned them over to the Nazis, "Haaretz Online" 11.02.2017, https://www.haaretz.com/world-news/.premium. MAGAZINE-orgy-of-murder-the-poles-who-hunted-jews-and-turned-them-in-1.5430977 (14.08.2020).

2 A. Leszczyński Na likwidację Żydów pojechałem. Kowalski Jan (wywiad z Janem Grabowskim), "Gazeta Wyborcza (Magazyn Świąteczny)" 30-31.07.2016; J. Grabowski, D. Libionka Wsadzili nas na wozy, powieźli jak bydło. Bezdroża «polityki historycznej». Muzeum w Markowej, "Gazeta Wyborcza (Magazyn Świąteczny)" 10-11.12.2016; J. Grabowski, D. Libionka Pomagali i zabijali: Muzeum w Markowej. Polemika, "Gazeta Wyborcza (Magazyn Świąteczny)" 7-8.01.2017; M. Szpytma Czyje to bezdroża? Muzeum w Markowej. Polemika, "Gazeta Wyborcza (Magazyn Świąteczny)" 7-8.01.2017; J. Grabowski, D. Libionka Bezdroża polityki historycznej. Wokół Markowej, czyli o czym nie mówi Muzeum Polaków Ratujących Żydów podczas II Wojny Światowej im. Rodziny Ulmów ,"Zagłada Żydów. Studia i Materiały” 2016 nr 12, s. 619-642.

3 J. Grabowski, D. Libionka Wsadzili nas na wozy, powieźli jak bydło...

4 F. Peters Towards a balanced tribute to the Polish Righteous? The Ulma Family Museum of Poles Saving Jews in Markowa, "Cultrues of History" 8.12.2016, www.cultures-of-history.uni-jena.de/ exhibitions/poland/towards-a-balanced-tribute-to-the-polish-righteous-the-ulma-familymuseum-of-poles-saving-jews-in-markowa/ (29.03.2020). Wszystkie teksty niemieckie i angielskie tłumaczone przez autorkę. 
on również nadzieję, że Muzeum będzie pobudzało do głębszej refleksji nad dylematami, przed którymi stawali zarówno Polacy, jak i Żydzi wobec niemieckiego terroru okupacyjnego.

Ekspozycje muzealne są medium niezwykle złożonym. Odwołują się zarówno do intelektu, jak i do zmysłów i emocji zwiedzających. Oddziałują na wielu poziomach: wizualnym, tekstowym, dźwiękowym i poprzez aranżację przestrzeni5. Odbiór wystawy może się znacznie różnić, zależnie od wcześniejszego poziomu wiedzy oraz wrażliwości zwiedzającego, a również tak prozaicznych czynników, jak czas spędzony na jej oglądaniu. Choć opinie historyków i muzealników na temat danej wystawy historycznej są bardzo cenne, ich wrażenia mogą w istotny sposób odbiegać od doznań przeciętnego odbiorcy. Aby określić realny wpływ danego muzeum na zwiedzających, konieczne jest przeprowadzenie badań nad publicznością.

Jak odbierane jest więc Muzeum Ulmów przez zwiedzających? Na ile jego recepcja różni się od odbioru dwóch, powstałych nieco wcześniej i budzących mniejsze kontrowersje, polskich muzeów poświęconych osobom ratującym Żydów podczas II wojny światowej - Apteki pod Orłem w Krakowie i Willi Żabińskich w Warszawie? Aby choć częściowo odpowiedzieć na te pytania postanowiłam zanalizować wpisy w księgach gości tych muzeów. Interesuje mnie przy tym nie tyle, jak zwiedzający oceniają badane ekspozycje, ale jak są one przez nich definiowane. Co jest według autorów komentarzy wiodącym tematem tych prezentacji muzealnych, kogo i co mają one upamiętniać, jakie emocje wywołują u zwiedzających?

\section{Księgi gości jako źródło do badań recepcji ekspozycji muzealnych}

Badania nad recepcją ekspozycji muzealnych, w tym badania ankietowe metodą grup fokusowych czy prowadzenie indywidualnych wywiadów ze zwiedzającymi, wymagają znacznego nakładu pracy, czasu i pieniędzy. Choć badania te w ciągu ostatnich dekad znacznie się rozwinęły, nadal tylko niewiele muzeów może sobie pozwolić na systematyczne ich prowadzenie ${ }^{6}$. Z tych

5 Na temat złożoności ekspozycji muzealnych jako medium oraz metod ich analizy patrz m.in.: J. Scholze Medium Ausstellung. Lektüren musealer Gestaltung in Oxford, Leipzig, Amsterdam, Berlin, Transcript, Bielefeld 2004, s. 11-39. T. Thiemeyer Geschichtswissenschaft. Das Museum als Quelle, w: Museumsanalyse. Methoden und Konturen eines neuen Forschungsfeldes, Hrsg. von J. Baur, Transcript, Bielefeld 2010, s. 73-94.

6 Na temat różnych metod badań recepcji ekspozycji muzealnych patrz m.in.: E. Hooper-Greenhill Museums and their Visitors, Routledge, London: 1994, s. 69-83; tegoż Studying Visitors, w: 
samych pragmatycznych względów również muzeolodzy często ograniczają się do analizy ekspozycji, rezygnując z badań nad ich publicznym odbiorem. Tymczasem księgi gości pozwalają w stosunkowo łatwy sposób zebrać bogaty materiał do analizy. Ostatnio coraz więcej badaczy korzysta z tego źródła w odniesieniu zarówno do aktualnych, jak i minionych ekspozycji?

Jak każda inna metoda badawcza i ta ma jednak ograniczenia. Niektórzy badacze twierdzą, że wpisy w księgach gości, jako że nie są reprezentatywne, nie oddają w trafny sposób tego, jak dana ekspozycja jest odbierana przez zwiedzających ${ }^{8}$. Tylko niewielki odsetek najbardziej zaangażowanych gości muzeum pozostawia komentarze. Wpisy te często też mają czysto kurtuazyjny charakter. Tamar Kartiel, który analizował wpisy w księgach gości w izraelskich muzeach osadnictwa żydowskiego, pisze: „Księgi gości nadają komentarzom zwiedzających niezwykle konwencjonalną formę odwołującą się do tradycji pochwał wygłaszanych przez gości wobec gospodarzy. Wpisy te potwierdzają jedynie, że muzeum wypełniło swoja misję"9. Inne badania przeczą jednak takiej generalizacji. Chaim Noy zwraca uwagę na publiczny charakter tych ksiąg i określa je jako „interaktywną scenę, na której tworzy się znaczenia"10. Mary Alexander, która analizowała wpisy osób zwiedzających czasową ekspozycję pokazywaną w 1999 roku w Smithonian's National Museum of American History, poświęconą historii zakładów wyzyskujących tanią siłę roboczą, pisze, że była zaskoczona „poziomem refleksji i powagą, z jaką zwiedzający podchodzili do tematu wystawy"11.

A Companion to Museum Studies, ed. by S. Macdonald, Wiley-Blackwell, London 2006, s. 362-376; G. E. Hein Learning in the Museum, Routledge, London 1998, s. 100-134.

7 S. Macdonald Accessing audience: visiting visitor books, "Museum \& Society" Nov. 2005 No. 3/2, S. 119-136.

8 A. J. Pekarik Understanding Visitor Comments: The Case of Flight Time Barbie, "Curator" March 1997 Vol. 40/1, s. 56-57, 66-67.

9 T. Kartiel Performing the past: A study of Israeli settlement museums, Routledge, New York-London 1997, s. 71 (przyp. 5). Cyt. za: S. Macdonald Accessing audience, s. 121. Por. też: A. J. Pekarik Understanding Visitor Comments, s. 66-67. I. Ross Uncharted territory: Visitor books of Indian museums. The Madhya Pradesh Tribal Museum in Bhopal - a case study " Museum \& Society" March 2017 No. 15/1, S. 104.

Ch. Noy Pages as stages: A performance approach to visitor books, "Annals of Tourism Research" April 2008 Vol. 35/2, s. 511.

11 M. Alexander Do visitors get it? A Sweatshop Exhibit and Visitors' Comments, "The Public Historian" Summer 2000 Vol. 22/3, s. 86. 
W moich badaniach istotnie tylko nieliczne komentarze zawierają krytykę, a i ta formułowana jest zazwyczaj bardzo oględnie. Ale choć większość wpisów ma kurtuazyjny charakter, ich treść wykracza często poza standardowe zwroty typu: „Dziękujemy za wspaniałą lekcję historii” i pozwala wnioskować, jakie znaczenie autorzy przypisują oglądanym ekspozycjom. Grzecznościowy charakter wpisów nie stanowi więc w tym przypadku przeszkody, interesuje mnie bowiem nie poziom satysfakcji z wizyty w muzeum, ale to, jak zwiedzający definiują to miejsce ${ }^{12}$.

Innym problemem przy analizie wpisów w księgach gości jest, że dysponujemy tylko bardzo wyrywkowymi informacjami na temat ich autorów, ich płci, wieku, miejsca zamieszkania, zawodu czy poziomu wykształcenia. W przypadku niniejszej analizy dane takie byłyby tym bardziej pomocne, że badane muzea mają bardzo różną publiczność, co pokazuje poniża tabela.

Tabela 1

\begin{tabular}{|c|c|c|c|}
\hline $\begin{array}{c}\text { Nazwa } \\
\text { muzeum }\end{array}$ & $\begin{array}{c}\text { Roczna liczba } \\
\text { zwiedzających }\end{array}$ & $\begin{array}{c}\text { Udzial turystów } \\
\text { z Polski }\end{array}$ & $\begin{array}{c}\text { Udzial turystów } \\
\text { zagranicznych }\end{array}$ \\
\hline $\begin{array}{c}\text { Apteka pod Orłem } \\
\text { (dane z lat 2013-2016) }\end{array}$ & $55000-60000$ & $\begin{array}{c}10 \% \text { (w tym stosunko- } \\
\text { wo wielu mieszkańców } \\
\text { Krakowa } \\
\text { i innych większych } \\
\text { miast). }\end{array}$ & $90 \%$ \\
\hline $\begin{array}{c}\text { Willa Żabińskich } \\
\text { (dane z lat 2015-2016) }\end{array}$ & 5000 & $\begin{array}{c}\text { 20\% (w tym stosun- } \\
\text { kowo } \\
\text { wielu mieszkańców } \\
\text { Warszawy). }\end{array}$ & $20 \%$ \\
\hline $\begin{array}{c}\text { Muzeum Ulmów15 } \\
\text { (dane z lat 2016-2017) }\end{array}$ & 50000 & $\begin{array}{c}\text { 80-85\% (w tym sto- } \\
\text { sunkowo wielu miesz- } \\
\text { kańców Podkarpacia). }\end{array}$ & $\begin{array}{c}15-20 \% \text { (wśród nich } \\
\text { członkowie Polonii) }\end{array}$ \\
\hline
\end{tabular}

12 Por. też: P. Livingstone, E. Pedretti, B.J. Soren Visitor Comments and the Socio-Cultural Context of Science, "Museum Management and Curatorship" 2001 Vol. 19/4, s. 367-368.

13 A. Pióro Apteka pod Orłem - pamięć odzyskana. Dzieje Apteki pod Orłem jako przykład manipulacji pamięcią zbiorowq, w: Apteka pod Orłem: historia i pamięć, red. J. Gryta i in., Muzeum Historyczne Miasta Krakowa, Kraków 2013, s. 220. E-mail od Moniki Bednarek, 27.06.2017.

14 Rozmowa z Olgą Zbonikowską przeprowadzona przez autorkę, 13.04.2017.

15 Spotkanie z Anną Stróż, wtedy p.o. dyrektora Muzeum Ulmów, podczas podróży studyjnej do Markowej, 30.03.2017. 
Staram się zasygnalizować te różnice w mojej analizie, podając w tekście i w przypisach jak najwięcej informacji na temat autorów cytowanych komentarzy.

Pierwotnie w każdym muzeum zamierzałam udokumentować wpisy z pierwszego roku po otwarciu stałej ekspozycji. Okazało się jednak, że muzea te różnią się znacznie pod względem liczby zwiedzających (patrz tabela 1). Różna jest też częstotliwość wpisów w księgach gości. Materiał był więc bardzo nierówny objętościowo. Problemem okazało się też,że wpisy pochodzą z różnych okresów. W ostatnich latach w Polsce zaszły głębokie zmiany społeczne i polityczne, zmieniła się też polityka historyczna, w tym oficjalna narracja dotycząca relacji polsko-żydowskich podczas II wojny światowej oraz miejsca, jakie w opowieści tej zajmują „Sprawiedliwi”. Nasuwa się więc pytanie, na ile różnice między wpisami zebranymi w analizowanych muzeach w latach 2013-2014 oraz 2015-2016 oddają rzeczywiste różnice w sposobie ich oddziaływania, a na ile stanowią one jedynie pochodną zmiany nastrojów społecznych, jaka zaszła w Polsce w badanym okresie. Aby to zweryfikować, w Aptece pod Orłem wpisy z okresu od marca 2013 do lutego 2014 roku uzupełniłam o wpisy z 2016 roku. W przypadku muzeum w Markowej, z uwagi na ogromną liczbę komentarzy, sporządziłam tylko dokumentację obejmującą pierwsze pięć miesięcy po otwarciu muzeum, czyli okres od marca do sierpnia 2016 roku. W przypadku Willi Żabińskich, ze względu na niewielką liczbę gości, uwzględniłam wpisy powstałe jeszcze przed jej oficjalnym otwarciem, czyli od stycznia 2015 aż do czerwca 2018 roku. Mimo to zebrany materiał nadal znacznie różni się pod względem objętości'16.

Analiza miała charakter jakościowy. Z zebranej dokumentacji wyselekcjonowałam te komentarze, które wykraczały poza podpis lub czysto kurtuazyjne podziękowania. Szczególnie interesowały mnie te wpisy, które zawierały nie tylko techniczną ocenę muzeum, np. że jest ono nowoczesne albo interaktywne, ale odnosiły się też do kwestii merytorycznych. Biorę pod uwagę teksty w języku polskim, hebrajskim, angielskim i niemieckim ${ }^{17}$. Dane liczbowe

16 Materiałzebrany w Aptece pod Orłem obejmuje 670 stron, w Muzeum Ulmów 430, a w Willi Żabińskich 30 stron. Przy czym liczba stron daje tylko ogólny wyobrażenie o objętości zebranego materiału, ponieważ zależnie od formatu księgi gości na jednej stronie mieści się różna liczba wpisów.

17 Wpisy w języku angielskim i niemieckim tłumaczyłam sama. Wpisy w języku hebrajskim zostały przetłumaczone przez Martę Stankiewicz. 
dotyczące wpisów z poszczególnych muzeów poddanych głębszej analizie przedstawia tabela 2 .

\section{Tabela 2}

\begin{tabular}{|c|c|c|c|c|c|}
\hline $\begin{array}{c}\text { Nazwa } \\
\text { muzeum }\end{array}$ & $\begin{array}{c}\text { Wpisy w księgach } \\
\text { gości za okres }\end{array}$ & $\begin{array}{c}\text { Liczba } \\
\text { wpisów } \\
\text { poddanych } \\
\text { analizie } \\
\text { ogółem }\end{array}$ & $\begin{array}{c}\text { Wpisy } \\
\text { w j.pol- } \\
\text { skim }\end{array}$ & $\begin{array}{c}\text { Wpisy } \\
\text { w. hebraj- } \\
\text { skim }\end{array}$ & $\begin{array}{c}\text { Wpisy } \\
\text { w. angiel- } \\
\text { skim i nie- } \\
\text { mieckim }\end{array}$ \\
\hline $\begin{array}{c}\text { Apteka } \\
\text { pod Orłem }\end{array}$ & $16.03 .2013-28.02 .2014$ & 167 & 36 & 21 & 110 \\
\cline { 2 - 6 } & $15.01-31.12 .2016$ & 206 & 19 & 45 & 142 \\
\hline $\begin{array}{c}\text { Willa Żabiń- } \\
\text { skich }\end{array}$ & $26.012015-29.06 .2018$ & 42 & 5 & 13 & 29 \\
\hline $\begin{array}{c}\text { Muzeum } \\
\text { Ulmów }\end{array}$ & $17.03 \cdot-11.08 .2016$ & 288 & 239 & 15 & 34 \\
\hline
\end{tabular}

Wyselekcjonowane komentarze podzieliłam na kategorie wyłaniające się $\mathrm{z}$ badanego materiału, przy czym niektóre $\mathrm{z}$ tych kategorii pojawiały się tylko w jednym lub dwóch muzeach, inne okazały się wspólne dla wszystkich badanych ekspozycji18.

\section{Co mówią nam wpisy w księgach gości o recepcji analizowanych muzeów?}

\section{Apteka pod Orłem}

Apteka pod Orłem jest najstarszym z analizowanych tu muzeów ${ }^{19}$. Jej właściciel Tadeusz Pankiewicz był jednym z niewielu Polaków, którym Niemcy pozwolili zostać na terenie krakowskiego getta ${ }^{20}$. Apteka stała się nie tylko ważnym miejscem spotkań i punktem kontaktowym; Pankiewicz oraz

18 Podobną metodę stosuje wielu badaczy. Patrz m.in.: S. Macdonald Accessing audiences, s. 123124. P. Livingstone, E. Pedretti, B.J. Soren Visitor Comments and the Socio-Cultural Context of Science, s. 360-361.

19 Zob. http://www.mhk.pl/oddzialy/apteka-pod-orlem (16.04.2020). Szerszą analizę wszystkich trzech omawianych tu ekspozycji przeprowadzam w: Z. Wóycicka Global patterns, local interpretations: New Polish museums dedicated to the rescue of Jews during the Holocaust, "Holocaust Studies: A Journal of Culture and History" 2019 Vol. 25/3 - Special Issue: Disputed Holocaust Memory in Poland, s. 248-272. 
jego współpracowniczki, Irena Droździkowska, Aurelia Danek-Czortowa oraz Helena Krywaniuk, pomagali też mieszkańcom getta, m.in. ukrywając ludzi podczas łapanek i akcji deportacyjnych oraz dostarczając darmowe leki potrzebującym. W 1947 roku Pankiewicz opublikował swoje okupacyjne wspomnienia, w których dał świadectwo zagłady żydowskiej społeczności Krakowa ${ }^{21}$.

W latach 6o. apteka została zlikwidowana. Pierwsza, skromna wystawa powstała tam dopiero w 1983 roku, w dwa lata po przyznaniu Pankiewiczowi medalu Sprawiedliwych wśród Narodów Świata ${ }^{22}$. Pierwotnie muzeum podlegało Urzędowi Dzielnicowemu Kraków-Podgórze, w 2004 roku zostało przekształcone w oddział Muzeum Historycznego Miasta Krakowa. Wtedy też otwarto nową, znacznie większą ekspozycję historyczną. Ostatniej przebudowy i modernizacji wystawy dokonano w 2013 roku.

Choć muzeum znajduje się w historycznym miejscu, wnętrze apteki stanowi rekonstrukcję. Wystawa opowiada historię za pomocą oryginalnych eksponatów, fotografii oraz relacji świadków, opatrzonych komentarzem kuratorskim. Celem muzeum jest, jak czytamy na stronie internetowej, upamiętnienie „Holokaustu krakowskich Żydów oraz postaci Tadeusza Pankiewicza, Sprawiedliwego wśród Narodów Świata"23.

Głównym narratorem ekspozycji jest Pankiewicz. Wynika to z koncepcji muzeum, które ma opowiadać historię krakowskiego getta widzianą z okien apteki. Silnie zaznacza się jednak także perspektywa żydowska. $\mathrm{Na}$ wystawie cytowane są liczne relacje i wspomnienia mieszkańców dzielnicy zamkniętej. Muzeum ukazuje socjalną, kulturową, religijną i polityczną różnorodność żydowskiej społeczności Krakowa. Wystawa prezentuje różne aspekty życia w getcie, tj. głód i niedożywienie, praca czy życie kulturalne. Ukazuje ona też różne sposoby radzenia sobie z okupacyjną rzeczywistością. Tak więc protagonistami opowieści są zarówno pracownicy apteki, jak i inni mieszkańcy podgórskiego getta, w tym członkowie żydowskich organizacji samopomocowych i zbrojnego ruchu oporu, jak również członkowie Judenratu czy policji żydowskiej. Przestawiono również sylwetki innych pomagających, zarówno Polaków, jak i Niemców. Na wystawie nie ma natomiast mowy o szmalcownikach ani o roli polskiej policji granatowej

21

\footnotetext{
T. Pankiewicz Apteka w getcie krakowskim, Świat i Wiedza, Kraków 1947.

Na temat powojennej historii apteki patrz m.in: A. Pióro Apteka pod Orłem.

Zob. www.mhk.pl/oddzialy/apteka-pod-orlem (24.04.2017).
} 
w pilnowaniu i likwidacji getta, zaś o zjawisku delatorstwa wspomniano jedynie na marginesie ${ }^{24}$.

\section{Recepcja}

Apteka pod Orłem oceniana jest w większości wpisów bardzo pozytywnie, wręcz entuzjastycznie. Ich autorzy doceniają przede wszystkim nowoczesny, interaktywny charakter prezentacji,jak również to, że jej przekaz dostosowany jest do różnych grup odbiorców, że oddziałuje ona na zmysły, że można na niej dotknąć różnych rzeczy, a nawet je powąchać. Wielu zwiedzających chwali też sposób, w jaki ekspozycja wykorzystuje relacje świadków. Niektórzy podkreślają również, że jej aranżacja pozwala „przenieść się w czasie” 25 i „poczuć atmosferę dawnych dni"26. Pewien mieszkaniec Londynu stwierdził nawet, że wystawa jest „o wiele bardziej wciągająca” niż brytyjskie muzea, co „czyni doświadczenia ludzi w getcie znacznie bardziej namacalnymi"27. Często pada też określenie, że prezentacja jest niezwykle poruszająca.

Wielu, zarówno polskich, jak i zagranicznych turystów definiuje Aptekę jako „pamiątkę o człowieku wielkiego serca”28, „hołd dla jednego z mniej zna-

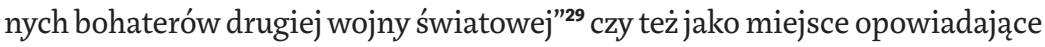
„Wspaniałą historię o ludzkim bohaterstwie" ${ }^{30}$. W niektórych wpisach autorzy, w tym przede wszystkim Izraelczycy oraz Żydzi z innych krajów świata, zwracają się do Tadeusza Pankiewicza z osobistymi podziękowaniami. Tak np. pewna polska Żydówka z Izraela pisze: „Może za późno, ale z całego serca dziękuję za pomoc dla Żydów podczas wojny"31. Choć większość zwiedzających postrzega farmaceutę przede wszystkim jako „niezwykłego człowieka,

24 Na ekspozycji pokazany jest wprawdzie jeden donos na Żydówkę i jej córkę ukrywające się po "aryjskiej stronie", ale stanowi on jedynie graficzne tło jednego z ekspozytorów, nie jest podpisany a jego treść nie została przetłumaczona na język angielski.

Księga Gości Apteki pod Orłem (KG ApO), 14.05.2016, j. pl., trzy kobiety.

KG ApO, 2.10.2013, j. pl., grupa emerytów z Politechniki Śląskiej.

KG ApO, b.d. (sierpień 2013), j. ang., mężczyzna, Wielka Brytania - Londyn.

KG ApO, 23.03.2013, j. pl, kobieta.

KG ApO, b.d. (sierpień 2013), j. ang., dwie osoby, Wielka Brytania - Manchester.

KG ApO, b.d. (lipiec 2016), j. ang., trzy osoby, Wielka Brytania - Loughborough.

KG ApO, b.d. (07.2016), j. pl., kobieta, Izrael. 
który ratował Żydów, narażając własne życie”32, niektórzy widzą w nim również „świadka wyniszczenia i mordowania Żydów” ${ }^{\text {33 }}$ oraz kronikarza getta krakowskiego. W wielu komentarzach wspominane są też, choć nie z nazwiska, pracujące w aptece kobiety.

Postawa Pankiewicza i jego współpracowniczek nie jest przy tym raczej traktowana jako reprezentatywna dla społeczeństwa polskiego. Natrafiłam tylko na dwa polskojęzyczne komentarze, w których Apteka określona została jako „pomnik polskiej pomocy narodowi żydowskiemu”" ${ }^{\text {"34 }}$ czy też miejsce ukazujące „prawdziwe przeżycie z okresu wojny pomiędzy Polakami i Żydami"35. Inny zwiedzający uznał Pankiewicza i jego współpracowniczki za ludzi, „którzy zasługują, by o nich pamięć trwała na wieki - jako wielkich patriotów" ${ }^{\prime 36}$. Prócz tego autorzy wpisów nie odnoszą się do zbiorowości narodowych, chyba że do Żydów jako ofiar Zagłady lub, rzadziej, do Niemców jako sprawców. W większości komentarzy, w których mowa o pracownikach apteki, zwraca się raczej uwagę na wyjątkowość tych postaci. I tak jeden ze zwiedzających wyraża żal, że „tacy ludzie byli w mniejszości”" ${ }^{37}$. W innych wpisach aptekarz określany jest jako „jeden z dziesięciu sprawiedliwych"38 lub „promień człowieczeństwa pośród bestialstwa” ${ }^{39}$. Izraelscy turyści podkreślają niekiedy, że Pankiewicz i inni Sprawiedliwi wśród Narodów Świata to jednostki wyjątkowe we wrogim Żydom świecie i że "gdyby było więcej ludzi takich jak właściciel apteki, świat by wyglądał inaczej, wtedy i dzisiaj!"40

Według innych historia Pankiewicza pozwala, mimo ogromu zbrodni popełnionych podczas II wojny światowej, zachować wiarę w człowieka. „Niepokojące widzieć, co ludzie mogą uczynić innym ludziom, jak okrucieństwo rozkwita, gdy tylko istnieją ku temu «odpowiednie» warunki" - pisze niemiecka turystka. „Ale, dzięki Bogu, są/byli też tacy ludzie jak Tadeusz Pankiewicz,

KG ApO, 20.09.2013, j. hebr., kobieta - delegacja szkoły Galili z Kfar Saby, Izrael.

KG ApO, 21.03.2013, j. pl., mężczyzna - mgr farmacji, Kraków.

KG ApO, 31.01.2014, j. pl., kobieta.

KG ApO, 22.07.2013, j. pl.

KG ApO, 10.04.2013, j. pl., mężczyzna.

KG ApO, 17.03.2016, j. ang., mężczyzna, Irlandia.

KG ApO, b.d. (05.2016), j. niem.

KG ApO, 25.08.2013, j. ang., kobieta, Wielka Brytania - Południowa Walia.

KG ApO, 9.10.2016, j. hebr., małżeństwo, Izrael - Kfar Saba.
} 
którzy bezinteresownie pomagali innym. Dzięki takim ludziom jak on, mam nadal wiarę w człowieczeństwo"41. To, że postawa Pankiewicza pozwala odzyskać zaufanie do świata i ludzkości, podkreślają zwłaszcza Izraelczycy oraz Żydzi z innych krajów świata. I tak w komentarzu izraelskich licealistów czytamy: „Ulżyło nam, że byli też dobrzy ludzie, którzy pomagali i wspierali Żydów mimo wszelkich trudności"42 . "Jeden sprawiedliwy człowiek w Sodomie! piszą członkowie żydowskiej organizacji Derech HaEmet z Meksyku - może przywrócić trochę zaufania do ludzkości, która obserwuje obojętnie, bez łez"43.

Przez niektórych zwiedzających Apteka pod Orłem postrzegana jest też jako miejsce, którego zadaniem jest kształtowanie postaw przyszłych pokoleń. Przy tym tylko w jednym komentarzu Tadeusz Pankiewicz postawiony został jako wzór patriotyzmu. Apteka to „doskonały pomysł - piszą jego autorzy - na naukę historii, przetrwania pamięci o Żydach, wdrożenia poczucia patriotyzmu i wychowania pokolenia Polaków, którzy zrozumieją, że świat bez wojen jest tak bardzo trudno utrzymać" ${ }^{44}$. Pozostali goście muzeum widzą w Pankiewiczu i jego współpracowniczkach bardziej uniwersalny wzór odwagi i człowieczeństwa. „Pani Irena będzie od dziś moim wzorem do naśladowania"45 - pisze pewna kobieta o Irenie Droździkowskiej. „Dziękuję za przedstawienie tej ważnej historii” - czytamy w innym komentarzu. „Oby zainspirowała ona do okazania odwagi w nadchodzących czasach!"46.

Mimo że wiele wpisów podkreśla rolę pracowników Apteki pod Orłem w ratowaniu Żydów, jest też spora grupa zwiedzających - zarówno z Polski, jak i z zagranicy - którzy postrzegają aptekę również, a może nawet przede wszystkim, jako miejsce upamiętniające ofiary Zagłady i umożliwiające poznanie „historii getta krakowskiego"47. I tak uczniowie gimnazjum w Zakrzowie piszą, że apteka uświadomiła im, ,jak trudna była rzeczywistość w krakowskim getcie" ${ }^{48}$, zaś członkowie Akademickiego Koła Przewodników

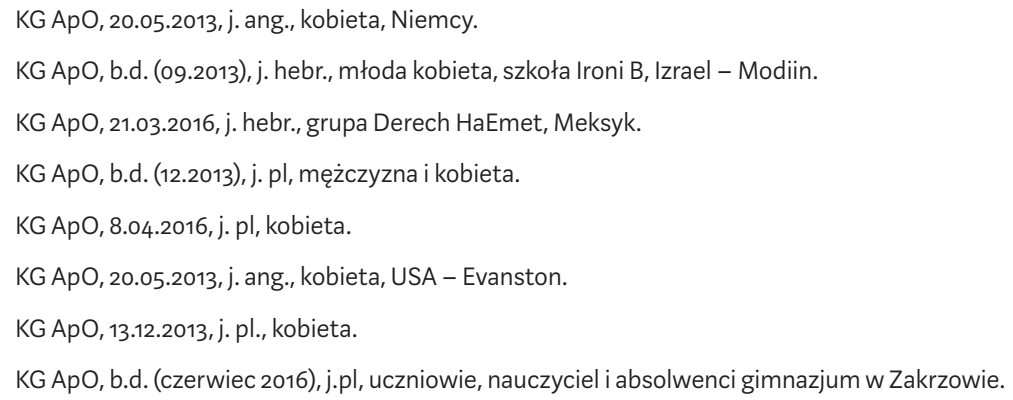


Górskich Bielsko-Biała dziękują w księdze gości „za przybliżenie bolesnej historii Narodu, który mieszkał z nami przez setki lat..." ${ }^{49}$. Inny zwiedzający stwierdził, że „dzieci i młodzież powinni obowiązkowo zobaczyć to miejsce, by docenić, w jakich czasach przyszło żyć ich żydowskim rówieśnikom"50. Również we wpisach turystów zagranicznych apteka określana jest jako muzeum opowiadające „o życiu w getcie"51 lub o „życiu Żydów w czasie Shoah"52. Dla niektórych zwiedzających złożenie wpisu w księdze gości stanowi również okazję do upamiętnienia członków własnej rodziny, którzy zginęli w Holokauście.

Wielu gości apteki docenia fakt, że muzeum daje wgląd w życie codzienne getta krakowskiego oraz w doświadczenia jego mieszkańców. Mowa również o tym, że wystawa przywraca twarz ofiarom Zagłądy i pozwala na „bardzo osobiste i poruszające spotkanie" ${ }^{53} \mathrm{z}$ nimi. Jedna z autorek określiła wystawę

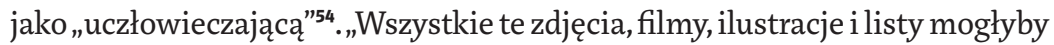
należeć do mojej rodziny" - pisze. „Gdybyśmy żyli w tamtych czasach, jako Żydówka, byłabym zamknięta z rodziną w getcie". W wielu komentarzach mowa tylko ogólnie o „tamtych strasznych czasach" ${ }^{55}$, „tragicznych latach"56 czy „okropnościach wojny i nienawiści” ${ }^{\text {57 }}$. Niektórzy zwiedzający doszukują się też w aptece bardziej uniwersalnego przekazu dotyczącego natury człowieka oraz jego zdolności zarówno do czynienia wielkiego dobra, do „czystej odwagi i bezinteresowności”, jak i absolutnego zła, „chciwości, nienawiści i morderstwa"58 . Jest też spora liczba wpisów, których główny przekaz można ująć jako: „Nigdy więcej takiego horroru”"59.

\footnotetext{
49 KG ApO, 23.04.2016, j. pl., Akademickie Koło Przewodników Górskich Bielsko-Biała. 
Wpisy w księgach gości Apteki pod Orłem z lat 2013-2014 i 2016 nie wykazują istotnych różnic. Zarówno w polskich, jak i w obcojęzycznych komentarzach z obu okresów pojawiają się te same wątki, a nawet podobne sformułowania. Jedynym nowym motywem, który znajdujemy się w księgach gości z 2016 roku, jest obawa przed wzrastającym w Europie separatyzmem, rasizmem i tendencjami autorytarnymi.,WW czasie, gdy nienawiść i rasizm zdają się powracać, miejsce to w szokujący sposób przypomina nie tak odległą przeszłość i okropności, do jakich prowadzi taki sposób myślenia”60 - pisze pewna Brytyjka. „Niszcz zło w zarodku!" - ostrzega turysta z Hamburga. „W tych imponujących historycznych wnętrzach, czerpiąc doświadczenie z przeszłości, patrzę w przyszłość. We wszystkich krajach Europy trzeba dławić zło w zarodku, tak aby nie było miejsca na samowolę i dyktaturę"61. Podobnych wpisów jest więcej. Brak rozbieżności w wymowie komentarzy z lat 2013-2014 i 2016 sugeruje, że zmiany społeczne i polityczne, które zaszły w Polsce w tym okresie, nie miały istotnego wpływu na recepcję ekspozycji, choć stosunkowo niewielka liczba wpisów polskojęzycznych (39 i 19) nakazuje w tej kwestii ostrożność.

\section{Willa Żabińskich}

Podobnie jak Apteka pod Orłem, muzeum Żabińskich znajduje się również w miejscu historycznym, w willi na terenie warszawskiego Ogrodu Zoologicznego. W domu tym dyrektor zoo oraz jego żona, Jan i Antonina Żabińscy ukrywali podczas II wojny światowej Żydów62. Pomagali też mieszkańcom getta warszawskiego na inne sposoby, dostarczając im żywność i fałszywe dokumenty oraz przemycając ludzi na ,aryjską stronę". W 1965 roku otrzymali medal Sprawiedliwych wśród Narodów Świata.

Twórcą muzeum jest wspierająca warszawskie zoo Fundacja Panda. Rewitalizacja Willi Żabińskich została sfinansowana z funduszy europejskich ${ }^{63}$. Muzeum otwarto w maju 2015 roku. Jego misją jest, po pierwsze, upamiętnienie Jana i Antoniny Żabińskich, po drugie, stworzenie miejsca, w którym można by rozmawiać o ,tolerancji, solidarności i potrzebie pomagania

60 KG ApO, 16.10.2016, j. ang., kobieta, Wielka Brytania - Kent.

61 KG ApO, 7.02.2016, j. niem., Niemcy - Hamburg.

62 Zob. http://panda.zoo.waw.pl/willa-żabińskich (9.04.2020); http://wystawy.sprawiedliwi.org. $\mathrm{pl} /$ wystawa-en/zydzi-ukrywani-w-zoo. Wirtualne zwiedzanie muzeum: http://zoo.waw.pl/ willa/wirtualna-wycieczka.html (9.04.2020).

63 Rozmowa z Olgą Zbonikowską przeprowadzona przez autorkę, Warszawa 13.04.2017. 
innym"64. Wystawa nie prezentuje szerszego kontekstu historycznego, nie dostarcza informacji na temat Zagłady lub dziejów getta warszawskiego.

Projektanci zrekonstruowali wnętrze willi na podstawie zachowanych zdjęć i relacji świadków. Na wystawie brak jednak tekstów i można ją zwiedzać tylko z przewodnikiem. Głównymi protagonistami i bohaterami ekspozycji są Żabińscy. Osoby, którym udzielali pomocy, grają role drugoplanowe. Ponieważ wystawa w warszawskim zoo nie operuje tekstem, znacznie trudniej określić, z jakiej perspektywy prowadzona jest narracja. W ścisłym tego słowa znaczeniu muzeum nie ma własnego głosu i bardzo wiele zależy od przewodników. Jednak osobiste przedmioty ze spuścizny Żabińskich i wyposażenie willi mówią przede wszystkim o życiu, gustach i zainteresowaniach gospodarzy. Znacznie mniej dowiadujemy się o ukrywających się tam ludziach. Na wystawie widnieją jedynie ich imiona i nazwiska, pokazano kilka fotografii. Nie dowiadujemy się jednak, kim byli ci ludzie i jakie były ich wojenne losy. Wyjątek stanowią: rzeźbiarka Magdalena Gross - na wystawie prezentowane są jej prace - oraz entomolog Szymon Tenenbaum, który powierzył Żabińskiemu swoją kolekcję owadów. W muzeum można również obejrzeć nagranie filmowe z relacją jednej z osób, która ukrywała się u Żabińskich. Zgodnie z wypowiedzią jednej z twórczyń muzeum, również przewodnicy skupiają się bardziej na historii Żabińskich niż na losach ich podopiecznych, co, jak twierdzi, odpowiada oczekiwaniom zarówno polskich, jak i zagranicznych gości muzeum ${ }^{65}$.

\section{Recepcja}

Również w księdze gości Willi Żabińskich nie ma żadnych krytycznych wpisów, choć ton komentarzy jest nieco mniej entuzjastyczny niż w przypadku Apteki pod Orłem. Wielu zwiedzających wyraża podziękowania dla przewodników. Kilka osób wspomina, że podoba im się połączenie ekspozycji historycznej z wystawą zoologiczną. , To muzeum wzbudziło we mnie uczucie szczęścia + podniecenia” ${ }^{\prime 66}$ - pisze jeden ze zwiedzających. „Wypchane tygrysy, wspaniałe akwarium, ucieczka, intryga, [nieczytelne]! Prawdziwa rzeźba ptaka [nieczytelne]! Zdumiewająca historia, wciągające doświadczenie”.

\footnotetext{
64 Tamże.

65 Tamże.

66 Księga Gości Willi Żabińskich (KG WŻ), 13.10.2015, j. ang., mężczyzna, USA - Nowy York.
} 
Willa postrzegana jest zarówno przez polskich, jak i zagranicznych gości przede wszystkim jako miejsce upamiętnienia Jana i Antoniny Żabińskich. Określani są oni jako ludzie wyjątkowi, obdarzeni szczególną „odwagą,,,życzliwością" i „człowieczeństwem." Jest to „[bardzo wyjątkowe miejsce, które świadczy o niezwykłej odwadze i człowieczeństwie ludzi, którzy narażali swoje życie, ratując naszych ziomków"67 - pisze małżeństwo z Izraela. Muzeum to budzi, czytamy w innym, polskim komentarzu, „ogromne emocje i szacunek dla Państwa Żabińskich"68. Niektórzy zwiedzający dają też wyraz wdzięczności. I tak delegacja izraelska, która odwiedziła muzeum wiosną 2017 roku, złożyła w księdze gości podziękowania „wspaniałej rodzinie, która uratowała wielu ludzi i tym samym uratowała cały świat"69. Inny zwiedzający pozostawił wpis: „Dziękuję za waszą życzliwość i odwagę. Stanowicie dla nas inspirację"70.

Znaleźć można jednak kilka komentarzy, w których Willa Żabińskich definiowana jest nie jako miejsce upamiętniające heroiczne jednostki, ale jako „przykład «zwykłego» bohaterstwa Polaków wobec Żydów” cytowanego wpisu jest Jan Dziedziczak, ówczesny wiceminister spraw zagranicznych z ramienia PiS. Ale komentarze o podobnej wymowie pozostawiło też kilku gości zagranicznych. I tak delegacja Ambasady Królestwa Danii napisała, że muzeum daje „wspaniałą okazję, by zobaczyć polskie bohaterstwo i pomysłowość w ich najlepszym wydaniu"72. Gość z Florydy nazwał ekspozycję w warszawskim zoo „piękną historią polskiej dumy i ludzkiego współczucia"73. Zwraca również uwagę komentarz pozostawiony przez grupę turystów brazylijskich: „Wizyta w tym miejscu sprawia, że jako Żydzi, zaczynamy myśleć, że to bardzo ważne, aby odwiedzić Polskę i zobaczyć nie tylko to, co naziści zrobili Żydom, ale też to jak dobrzy Polacy Żydom pomagali"74.

67 KG WŻ, j. 3.06.2017, j. hebr., małżeństwo.

68 KG WŻ, 4.07.2015, j. pl., dwie osoby.

69 KG WŻ, 20,03.2017, j. hebr., delegacja państwowa do Polski z udziałem ocalonego z Holokaustu, Izrael - Aszkelon.

70 KG WŻ, b.d. (jesień 2015), j. ang.

71 KG WŻ, 28.11.2016, j. pl., wiceminister spraw zagranicznych Rzeczypospolitej Polskiej.

72 KG WŻ, 4.09.2015, j. ang., delegacja Ambasady Królestwa Danii.

73 KG WŻ, 6.29.2018, j. ang., USA - Floryda.

74 KG WŻ, 21.03.2018, j. ang., pięć osób, Brazylia - Rio de Janeiro. 
Inaczej niż w księgach gości Apteki pod Orłem, w których często wspomina się o mieszkańcach getta krakowskiego, w komentarzach pozostawionych w księdze gości Willi Żabińskich brak niemal zupełnie odniesień do losów warszawskich Żydów podczas II wojny światowej. Najwyraźniej muzeum to nie jest postrzegane jako miejsce, w którym można dowiedzieć się czegoś więcej na temat Holokaustu lub jako miejsce upamiętniające ofiary Zagłady. Co ciekawe, dotyczy to również Izraelczyków oraz innych żydowskich zwiedzających. Brak też wzmianek o osobach, którym Żabińscy pomagali. Wyjątek stanowi rodzina Kenigsweinów, z którą dwóch turystów izraelskich było zaprzyjaźnionych, co zmotywowało ich do odwiedzenia muzeum ${ }^{75}$. W pozostałych komentarzach mowa tylko ogólnie o uratowanych przez Żabińskich Żydach lub o „naszych ziomkach”.

\section{Muzeum Ulmów}

W odróżnieniu od dwóch wyżej omówionych placówek Muzeum Polaków Ratujących Żydów podczas drugiej wojny światowej im. Rodziny Ulmów nie znajduje się w miejscu historycznym, lecz w budynku wzniesionym specjalnie w tym celu, w odległości kilkuset metrów od miejsca, w którym stał dom jego patronów ${ }^{76}$. W latach 1942-1944 Józef i Wiktoria Ulmowie udzielili schronienia ośmiorgu Żydom z Markowej i Łańcuta, Saulowi Goldmanowi i jego czterem synom, Lei Didner z córką oraz Gołdzie Grünfeld ${ }^{77}$. W marcu 1944 roku granatowy policjant zadenuncjował ich niemieckiej żandarmerii. Ulmowie, ich sześcioro dzieci oraz ukrywający się Żydzi zostali rozstrzelani. W 1995 roku Ulmom przyznano pośmiertnie medal Yad Vashem.

Inicjatorem i pierwszym dyrektorem muzeum był pochodzący z Markowej Mateusz Szpytma, wtedy pracownik krakowskiego IPN. Głównym fundatorem i założycielem placówki był Sejmik Województwa Podkarpackiego. Otrzymała ona też dotację z Ministerstwa Kultury. Muzeum otwarto w marcu 2016 roku. Początkowo było ono filią Muzeum Zamku w Łańcucie, w 2017 roku zostało przekształcone w samodzielną instytucję kultury.

75 KG WŻ, 14.06.2015, j. hebr., kobieta, Izrael - Ramat Gan. 14.06.2015, j. hebr., małżeństwo, Izrael.

76 Zob.https://muzeumulmow.pl/pl/

77 M. Szpytma The risk of survival. The rescue of the lews by the Poles and the tragic consequences for the Ulma family from Markowa, IPN, Warszawa 2009, s. 75-79, http://www.yadvashem.org/ righteous/stories/ulma (25.04.2018).https://sprawiedliwi.org.pl/pl/historie-pomocy/historia-pomocy-rodzina-ulmow 
„Podstawowym celem MPRŻ jest - jak czytamy na stronie internetowej pokazanie bohaterskich postaw Polaków, którzy w czasie okupacji niemieckiej pomagali Żydom, ryzykując życie swoje i swoich rodzin"78. Muzeum Ulmów prezentuje się też jako „pierwsza w Polsce placówka muzealna zajmująca się tematyką ratowania ludności żydowskiej na okupowanych ziemiach polskich podczas Zagłady"79. Choć ambicje te nie zostały w pełni zrealizowane, zwiedzający mogą tam rzeczywiście zapoznać się nie tylko z losami Ulmów, ale z wieloma innymi przykładami pomocy udzielanej na Podkarpaciu ofiarom Zagłady. Ponadto na placu przed budynkiem muzeum znajdziemy wpuszczone w ziemię podświetlone tablice z nazwiskami Polaków z różnych części kraju, którzy ponieśli śmierć za pomoc udzieloną Żydom. Na tyłach muzeum znajduje się Sad Pamięci. Wzdłuż jego alejek umieszczono tabliczki z nazwiskami miejscowości na terenie przedwojennej Polski, w których mieszkały osoby odznaczone po wojnie medalem Sprawiedliwych wśród Narodów Świata.

We wstępnej części samej ekspozycji mowa jest zarówno o społeczności żydowskiej Podkarpacia w okresie międzywojennym, jak i o okupacyjnych losach Żydów i Polaków w tym regionie. Jednak stanowiąca trzon wystawy część poświęcona pomocy niesionej Żydom podczas II wojny światowej skupia się przede wszystkim na ratujących, a ich beneficjenci pozostają na drugim planie. Tylko w nielicznych przypadkach dowiadujemy się więcej na temat ich tożsamości i dalszych losów. Wystawa w Markowej opiera się przede wszystkim na polskich świadectwach. Choć prezentowanych jest tam również kilka relacji żydowskich, zdecydowanie dominuje perspektywa ratujących.

$\mathrm{Na}$ ekspozycji pojawia się też wątek polskich denuncjantów. Pokazano kilka donosów do władz niemieckich. Jednak tylko niektóre z nich dotyczą pomocy Żydom; pozostałe odnoszą się do innych przypadków łamania zarządzeń okupacyjnych. Wymowę dokumentów osłabia również fakt, że w odróżnieniu od przykładów niesienia pomocy, pochodzą one nie tylko z Podkarpacia, ale z różnych części Polski. Jak już wspomniano we wstępie, Muzeum Ulmów spotkało się ostrą krytyką Jana Grabowskiego i Dariusza Libionki, którzy zarzucają autorom ekspozycji przemilczanie informacji, które wskazują, że podczas gdy Ulmowie i kilka innych rodzin z Markowej ukrywało Żydów, ich sąsiedzi urządzali na nich polowania ${ }^{\mathbf{8 0}}$.

78 Zob. https://muzeumulmow.pl/pl/muzeum/o-muzeum (25.04.2018).

79 Zob.https://muzeumulmow.pl/pl/muzeum/o-muzeum/ (28.05.2020)

80 J. Grabowski, D. Libionka Bezdroża polityki historycznej. Por też: M. Szpytma Zbrodnia na ludnościżydowskiej w Markowej w 1942 roku w kontekście postępowań karnych z lat 1949-1954, „Zeszyty 
Warto też zauważyć, że Muzeum Ulmów nie definiuje polskości przez pryzmat obywatelstwa, ale przynależności do grupy etnicznej lub wyznaniowej. Choć Podkarpacie było przed wojną wielokulturowe, na wystawie nie podano ani jednego przykładu Ukraińca lub grekokatolika ratującego Żydów.

\section{Recepcja}

Księga Gości Muzeum Ulmów zawiera bardzo liczne, w znakomitej większości pozytywne komentarze. Turyści podkreślają zwłaszcza walory architektoniczne budynku oraz zwracają uwagę, że „koresponduje [ona] z wpisaną w nią treścią" ${ }^{\text {. }}$ „Forma - prostota, światło, mleczne szkło, surowy beton - wszystko to sprzyja odbiorowi i wzmacnia piękny przekaz!"82 Niektórzy chwalą też nowoczesny i interaktywny charakter ekspozycji.

Muzeum w Markowej interpretowane jest zarówno przez polskich, jak i zagranicznych gości przede wszystkim jako miejsce upamiętniające „bohaterską rodzinę śp. Ulmów”"83, „Sprawiedliwych wśród Narodów Świata, którzy pomogli ocalić Żydów podczas drugiej wojny światowej"84. Niektórzy definiują je szerzej, też jako miejsce poświęcone pamięci „innych rodzin mieszkających na Podkarpaciu ratujących życie rodzin Żydowskich"85.

Przez niektórych Ulmowie oraz inni bohaterowie ekspozycji postrzegani są jako uniwersalny wzór odwagi i człowieczeństwa. „To miejsce to symbol tego, co w człowieku najlepsze - czytamy w jednym z komentarzy - wsparcie i współodczuwanie z drugim człowiekiem"86. „Ci Polacy, którzy ratowali naszych braci Żydów w Markowej - pisze pewien ksiądz - wyznaczyli nam drogę życia, aktualną także teraz, przypominają

Historyczne WiN" 2014 nr 40, s. 39-66; T. Markiel, J. Skibińska «lakie to ma znaczenie, czy zrobili to z chciwości?» Zagłada Domu Trynczerów, Stowarzyszenie Centrum Badań nad Zagładą, Warszawa 2011; J. Grabowski Na posterunku. Udział polskiej policji granatowej i kryminalnej w zagładzie Żydów, Czarne, Wołowiec 2020, s. 123-124, 175-177, 245-247.

81 Księga Gości Muzeum Ulmów (KG MU), 28.05.2016, j. pl., kobieta (ur. 1944) z trzyosobową rodziną.

82 KG MU, 22.06.2016, j. pl., trzy osoby, Poznań.

83 KG MU, 4.06.2016, j. pl., mężczyzna.

84 KG MU, 31.03.2016, j. hebr., małżeństwo, Izrael - Elkana.

85 KG MU, 20.04.2016, j. pl., uczniowie i nauczyciele LO im. Św. Stanisława Kostki, Kamieniec.

86 KG MU, 17.03.2016, j. pl., kobieta. 
o bezcenności każdego człowieka"87. Muzeum to pozwala utrzymać pamięć „o zwykłym człowieczeństwie - za nieskończenie wysoką cenę"88 - napisał inny zwiedzający.

Inne wpisy, głównie polskich zwiedzających, sugerują, że czyny Ulmów motywowane były religijnie, że ratując Żydów, dawali oni „świadectwo swej wiary" ${ }^{\text {"99 }}$, a ich postawa stanowi wzór „chrześcijańskiego miłosierdzia"90. Muzeum to, jak czytamy w jednym z komentarzy, uświadamia wszystkim, ,jakie wyzwanie stanowi bezkompromisowe życie zgodnie z Ewangelią" ${ }^{\prime \prime}$. Wielu zwiedzających wyraża też nadzieję na rychłą beatyfikację Ulmów. Często podkreśla się, że zginęli oni śmiercią tragiczną. „Wstrząsające wrażenie, cudowna Rodzina Ulmów. Wielka żałość, że zginęli"92 - piszą uczestnicy pielgrzymki z Wadowic. Inni goście muzeum wyrażają „ból i cierpienie po wielkich bohaterach rodziny Ulma!!!"93 W jednym z anglojęzycznych komentarzy czytamy: „To wspaniałe muzeum. Pozwoliło mi ono naprawdę docenić to, co się tu wydarzyło, i ostateczną ofiarę rodziny Ulmów"94. Patroni muzeum określani bywają jako męczennicy, którzy złożyli „ofiarę krwi i życia”95 lub, jak napisał pewien Izraelczyk, „swoją śmiercią uświęcili imię boże"96. Zwraca uwagę, że w większości komentarzy mowa jest tylko o Ulmach. Mało kto wspomina o śmierci ukrywanych przez nich Żydów - ich imiona nie padają w żadnym $\mathrm{z}$ analizowanych wpisów.

Dla niektórych, choć niewielu, zwiedzających, muzeum w Markowej jest jednak nie tylko pomnikiem ludzi ratujących Żydów, ale też miejscem upamiętnienia ofiar Zagłady. Po wizycie w muzeum autorzy jednego z komentarzy wyrażają żal, „że tylu Żydów zginęło" ${ }^{\text {"97 }}$, zaś małżeństwo z Wrocławia pisze:

\footnotetext{
87 KG MU, 26.05.2016.

88 KG MU, 27.05.2016, j. niem.

89 KG MU, 15.05.2016, j.pl, pielgrzymka Akcji Katolickiej w Polsce.

90 KG MU, 12.04.2016, j. pl., Siostry Niepokalanki, Jarosław.

91 KG MU, b.d. (08.2016), j. ang., kobieta.

92 KG MU, 11.06.2016, j.pl, pielgrzymka, Wadowice.

93 KG MU, 29.04.2016, j. pl.

94 KG MU, b.d. (07.2016), j. ang., mężczyzna.

95 KG MU, 12.04.2016, j. pl., Siostry Niepokalanki, Jarosław.

96 KG MU, 05.2016, j. hebr., mężczyzna.

97 KG MU, 2.08.2016, j. pl., kobieta i dwóch mężczyzn.
} 
"Jesteśmy wstrząśnięci tragicznym losem Żydów i ratujących ich Polaków"98. Inni zwiedzający definiują muzeum jako „miejsce upamiętnienia Kaźni Polskich Żydów oraz ich zbawicieli, którzy oddali życie za ich ratowanie"99. Są też tacy, którzy interpretują wystawę jako uniwersalną opowieść o okrucieństwach wojny. Według nich muzeum powinno służyć temu, „żeby się to już nigdy nie powtórzyło"100.

Wielu zwiedzających definiuje Muzeum w Markowej w kategoriach etnicznych czy narodowych. W komentarzach często podkreślają, że bohaterami ekspozycji są Polacy. I tak kobiety z Koła Gospodyń Wiejskich Bajdy-Bratkówka składają podziękowania „za wybudowanie tak ważnego obiektu, w celu upamiętnienia bohaterskich czynów naszych Rodaków, którzy ryzykowali życie własne i własnych rodzin a mimo to podejmowali się ratowania żydowskich braci”101. W innym komentarzu czytamy, że jest to „małe muzeum z wielką historią w środku. Z historią o Polakach ratujących Żydów podczas II Wojny Światowej"102. Wiele komentarzy sugeruje też, że postawa Ulmów jest reprezentatywna dla ogółu polskiego społeczeństwa, a Muzeum w Markowej stanowi świadectwo tolerancji i bohaterstwa narodu polskiego. „«Warto być Polakiem» - Polakiem z naturalnym dążeniem do niesienia pomocy i tolerancji" - napisała ówczesna szefowa Kancelarii Prezesa Rady Ministrów RP Beata Kempa w dniu otwarcia muzeum ${ }^{103}$. „Historia bardzo ciekawa, prawdziwa, niosąca sławę na cały świat, - czytamy w innym miejscu - a w nim Polska wyróżniona"104. W innych komentarzach mowa o tym, że muzeum ukazuje istnienie w Polsce „etosu ratowania Żydów” ${ }^{105}$ lub że ekspozycja dowodzi, „że Polacy to wielki naród”106 . Tego typu wypowiedzi pojawiają się głównie w polskojęzycznych komentarzach, choć turyści zagraniczni

98 KG MU, 30.05.2016, j. pl., małżeństwo, Wrocław.

$99 \mathrm{KG} \mathrm{MU,} \mathrm{20.03.2016,j} \mathrm{jl.,} \mathrm{rodzina,} \mathrm{Mielec.}$

100 KG MU, 24.05.2016, j. pl., wycieczka z osiedlowego Domu Kultury, Klub Seniora, Rzeszów.

101 KG MU, 19.06.2016, j. pl., Koło Gospodyń Wiejskich, Bajdy-Bratkówka (Woj. Podkarpackie).

102 KG MU, 31.07.2016, j. pl., kobieta i mężczyzna.

103 KG MU, 17.03.2016, j. pl., Beata Kempa, Szefowa Kancelarii Prezesa Rady Ministrów RP.

104 KG MU, 9.07.2016, j. pl., dwie osoby.

105 KG MU, 15.07.2016, j pl., mężczyzna, prawnuk ludzi odznaczonych medalem Sprawiedliwych wśród Narodów Świata.

106 KG MU, b.d. (05.2016), j. pl., mężczyzna. 
niekiedy też piszą, że muzeum dowodzi bohaterstwa Polaków. I tak pewne małżeństwo z Holandii zostawiło komentarz: „Dobrze widzieć, że tak wielu dobrych Polaków pomagało Żydom podczas wojny" ${ }^{107}$. Zaś studenci jednego z amerykańskich uniwersytetów wyrazili podziękowania „za tak wzruszający pomnik siły i odwagi narodu polskiego"108.

Niemała grupa zwiedzających rozumie też Muzeum Ulmów jako bezpośrednią odpowiedź na oskarżenia o udział niektórych Polaków w Zagładzie. „Dobrze, że powstała taka wystawa - pisze pewien mężczyzna po obejrzeniu ekspozycji - że Polacy jednak pomagali Żydom a nie ich represjonowali, jak sądzą ludzie na świecie"109. Wpis w podobnym duchu pozostawił również jeden z członków gdańskiego Klubu „Gazety Polskiej”: „Proszę Boga, aby świat to docenił, co «robili» dla Żydów Polacy, narażając własne życie, i aby świat nie kłamał, ujmując tym bohaterom ich cześć"110. W innym miejscu czytamy: „Każdy młody człowiek powinien obejrzeć, poczytać, posłuchać i nie wierzyć już w oszczerstwa, że Polacy mordowali kogokolwiek w czasie wojny"111. Jako główni oszczercy wymieniani są, podobnie jak w czasie tzw. Kampanii Antysyjonistycznej lat 1967-1968, Izrael, Niemcy i Stany Zjednoczone. Do tego dochodzi Bruksela: „O tym wszystkim, co tu pokazano, trzeba nie tylko mówić, ale wręcz krzyczeć, tak by docierało szeroko, a zwłaszcza do Tel Awiwu i Nowego Jorku, a także Berlina, Brukseli i innych miejsc, gdzie nie znają tej historii, a pozwalają sobie nas pouczać"112.

W wypowiedziach tych wyraźnie pobrzmiewają echa prowadzonej od lat medialnej walki z „wadliwymi kodami pamięci”. Przy czym pojęciem tym określa się nie tylko jednoznacznie fałszywe i krzywdzące określenia typu „polskie obozy koncentracyjne” lub „polskie getta”, ale używa się go też w szerszym znaczeniu dla odparcia wszelkich, nawet uzasadnionych historycznie zarzutów o udział członków polskiego społeczeństwa w Zagładzie oraz czerpanie z niej korzyści materialnych ${ }^{113}$. Te dwa poziomy zlewają się

\footnotetext{
107 KG MU, b.d. (07.2016), j. ang., małżeństwo, Holandia.

108 KG MU, 12.05.2016, j. ang., studenci Uniwersytetu Villanova, USA.

109 KG MU, b.d. (04.2016), j. pl., mężczyzna.

110 KG MU, b.d. (maj 2016), j. pl., Klub Gazety Polskiej, Gdańsk i Tczew.

111 KG MU, b.d. (05.2016), j. pl., kobieta z synem i rodzicami.

112 KG MU, 2.05.2016, mężczyzna, Gdynia.

113 Patrz m.in.: Wadliwe kody pamięci. Zniekształcenie pamięci o zbrodniach międzynarodowych w dyskursie publicznym, red. A. Nowak-Far, Ł. Zamęcki, Wydawnictwa UW, Warszawa 2015.
} 
też w wypowiedziach gości Muzeum w Markowej. Bardzo dobrze, pisze kilku zwiedzających, „że nareszcie stało się jasne, jaką rolę odegrali Polacy w ratowaniu Żydów. Dobrze by też było zwrócić jeszcze raz uwagę, czyje dokładnie były te obozy zagłady"114. Nie brakuje też bezpośrednich odniesień do Sąiadów Jana Tomasza Grossa. „A więc nie tylko Jedwabne, ale też, a może przede wszystkim Markowa - panie prof. Gross"115 - czytamy w jednym z komentarzy. I dalej na tej samej stronie: „Panie Gross więcej obiektywizmu na sprawy żydowskie"116. Należy jednak podkreślić, że wśród analizowanych komentarzy brak tekstów o charakterze ewidentnie antysemickim. Znalazłam tylko jeden taki wpis. Jego autor podkreśla z jednej strony bohaterstwo Polaków w ratowaniu Żydów, z drugiej wysuwa zbiorowe oskarżenie wobec tych ostatnich o kolaborację ze Związkiem Radzieckim. „Dziękuję za wspaniałe muzeum, które pierwsze celowo odkłamuje mit Polaka «antysemity od urodzenia»" - pisze. „Należy mówić prawdę i o Polakach i o Żydach kolaborujących z bolszewikami przeciwko narodowi Polskiemu"117.

Tylko nieliczni goście muzeum jednoznacznie podważają czysto etniczne kategoryzacje. Zdziwiło mnie, pisze autor komentarza, „silne rozróżnienie na «nas» i «Żydów». Czy przedmiotem upamiętnienia nie jest tu właśnie poczucie wspólnoty między tymi grupami?"118. Jeden ze zwiedzających kwestionuje też pośrednio generalizacje dotyczące bohaterskiej postawy Polaków podczas II wojny światowej. „Ładne muzeum, wielkie uznanie dla TYCH, co pomagali w potrzebie!” - pisze. I dodaje: „Polecam też wizytę kilka kilometrów stąd na polach Kosiny - tam też jest pomnik, z którego niestety nie możemy być dumni"119. Również niektórzy izraelscy turyści podkreślają, że postawa rodziny Ulmów stanowiła raczej wyjątek niż regułę. Mowa o tym, że stanowili oni

114 KG MU, 3.04.2016, j. pl., dwie kobiety i dwóch mężczyzn.

115 KG MU, 26.07.2016, j. pl.

116 KG MU,26.07.2016, j. pl., małżeństwo.

117 KG MU, b.d. (04.2016), j. pl.

118 KG MU, maj 2016, j. pl.

119 KG MU, b.d. (07.2016), j. pl., mężczyzna. Na polach, w okolicy położonej niespełna $10 \mathrm{~km}$ od Markowej wsi Kosina znajduje się skromny pomnik z następującą inskrypcją: „Tu spoczywają Szymon Kirschner, lat 58, jego żona Chaja, lat 48 i ich 9-letnia córka Ita zamordowani przez zbrodniarzy hitlerowskich we wsi Kosina 14.VIII.1942." http://www.gminalancut.pl/asp/ pl_start.asp?typ=14\&sub=25\&menu=94\&strona=1 (12.04.2020). Szerzej na temat losu Żydów z Markowej i okolicznych miejscowości w latach 1942-1945 patrz: J. Grabowski, D. Libionka Bezdroża polityki historycznej, "Zagłada Żydów. Studia i Materiały” oraz J. Grabowski Na posterunku. 
„światło w ciemności” ${ }^{20}$ lub też zapalili „maleńką świeczkę dobra w świecie czerni i zła”21. Trzech Izraelczyków, których rodzina pochodzi z Przemyśla, napisało, że jest to „imponujące muzeum poświęcone odważnym ludziom, którzy narażając własne życie, ratowali Żydów, a niektórzy nawet zapłacili życiem”. Nie należy jednak zapominać, dodają, „że Polska była cmentarzem narodu żydowskiego"122.

\section{Podsumowanie}

Powyższa analiza pokazuje, że mimo tematycznego pokrewieństwa Apteka pod Orłem, Willa Żabińskich i Muzeum w Markowej postrzegane są w bardzo różny sposób. W przypadku polskich komentarzy różnice te wynikają zapewne nie tylko $\mathrm{z}$ innego sposobu prowadzenia narracji na omawianych ekspozycjach, ale wiążą się one też z faktem, że każde z tych muzeów ma inną publiczność. Nie dotyczy to jednak komentarzy obcojęzycznych, ponieważ profil turystów zagranicznych jest we wszystkich trzech muzeach podobny choć w Aptece pod Orłem i Willi Żabińskich jest ich proporcjonalnie więcej niż w Muzeum Ulmów. Komentarze angielskie, hebrajskie i niemieckie mogą zatem stanowić „grupę kontrolną" dla wpisów w języku polskim. Oczywiście istnieją teksty charakterystyczne dla ludzi pochodzących z różnych kręgów kulturowych. I tak np. w księdze gości Muzeum w Markowej odwołania do publikacji Jana Tomasza Grossa czy, szerzej, do „szkalowania” Polaków i oskarżania ich o udział w mordach na ludności żydowskiej znajdujemy jedynie w komentarzach polskojęzycznych. $Z$ drugiej strony tylko we wpisach w języku hebrajskim mowa jest o Polsce jako o "cmentarzu narodu Żydowskiego" czy o Ulmach jako o „maleńkiej świeczce dobra w świecie czerni i zła”. Mimo to różnice w sposobie postrzegania i interpretacji badanych ekspozycji dotyczą również wpisów obcojęzycznych i układają się w podobny wzór.

Zarówno w polskich, jak i obcojęzycznych komentarzach Apteka pod Orłem definiowana jest przede wszystkim jako miejsce upamiętniające Tadeusza Pankiewicza i jego współpracowniczki, ale teżjako miejsce dokumentacji i upamiętnienia zagłady krakowskich Żydów. Autorzy wpisów rzadko odwołują się do kategorii narodowych. Inaczej rozłożone są akcenty w księgach

\footnotetext{
120 KG MU, b.d. (07.2016), j. hebr., licealiści, Izrael - Ofra.

121 KG MU, 08.07.2016, j. hebr., kobieta, Izrael - Dolev.

122 KG MU, 29.06.2016, j. hebr., trzech Izraelczyków, których rodzina pochodzi z Przemyśla.
} 
gości w muzeach w Warszawie i Markowej. Tu w odbiorze zwiedzających na pierwszy plan wysuwają się Żabińscy, Ulmowie oraz inne osoby pomagające prześladowanym Żydom. Znacznie rzadziej wspomina się o szerszym kontekście Zagłady. Podczas jednak gdy o Janie i Antoninie Żabińskich pisze się jako o jednostkach wyjątkowych i stawia się je jako uniwersalny wzór odwagi i człowieczeństwa, historia bohaterów markowskiej ekspozycji postrzegana jest często, zarówno przez polskich, jak i zagranicznych turystów, jako świadectwo i symbol bohaterstwa narodu polskiego. Znacznie częściej niż w pozostałych muzeach autorzy wpisów używają wielkich kwantyfikatorów typu „Polacy”, „naród polski” lub „nasi rodacy”. Wyniki te nie wydają się przypadkowe i pokrywają się w znacznym stopniu z przeprowadzoną przeze mnie wcześniej analizą tych trzech ekspozycji, która ukazała się w ubiegłym roku na łamach Holocaust Studies ${ }^{123}$. Jednym z wniosków tej publikacji jest to, że choć wszystkie trzy muzea dotyczą podobnego zjawiska historycznego, każde z nich ma inną strukturę narracyjną, inaczej definiuje swoich protagonistów i bohaterów i opowiada historię z innej perspektywy.

Analiza wpisów w księgach gości nie pozwala uchwycić zmian w postawach zwiedzających przed obejrzeniem ekspozycji i po nim. Inne badania wykazują jednak, że wizyta w muzeum rzadko prowadzi do radykalnej zmiany postaw. Może ona jednak „wzmocnić zastane przekonania i poszerzyć horyzont zwiedzającego w pożądanym przez niego kierunku"124. Muzea działają więc jak pudła rezonansowe utrwalając i wzmacniając zastane postawy i wyobrażenia. Są to jednak specyficzne rezonatory, które reagują tylko na dźwięki o odpowiedniej częstotliwości. To, że w każdym z badanych muzeów wpisy w księgach gości zdają się układać w odmienny, charakterystyczny dla niego wzór, zdaje się sugerować, iż - mimo że zajmują się one pokrewną tematyką - każde z nich rezonuje inaczej. Przykładowo w księdze gości Muzeum w Markowej nawet izraelscy turyści odnoszą się głównie do pomagających, a nie do ofiar Zagłady. Z drugiej strony zapewne nawet najwierniejszy czytelnik prawicowej „Gazety Polskiej” nie zamieściłby w księdze gości Apteki pod Orłem polemicznej aluzji do publikacji Jana Tomasza Grossa, ponieważ ekspozycja nie daje do tego asumptu. Potwierdzenie tej hipotezy dotyczącej sposobu oddziaływania wszystkich trzech ekspozycji wymagałoby dalszych, pogłębionych badań.

123 Z. Wóycicka Global patterns, local interpretations...

124 V. Kirchenberg Besucherforschung in Museen. Evaluation von Ausstellungen, w: Museumsanalyse..., s. 175. 


\section{Abstract}

\section{Zofia Wóycicka}

GERMAN HISTORICAL INSTITUTE

"Thank You for Introducing to Us the History of Poles Saving /ews.": The Reception of Polish Museums of the "Righteous" through Guestbooks - Eagle Pharmacy,Żabiński Villa, Ulma Family Museum

The last decade has seen the establishment of no less than three historical exhibitions about Poles who rescued Jews during World War II: Tadeusz Pankiewicz's Eagle Pharmacy in Cracow (2013), the Żabiński Villa in Warsaw (2015) and the Ulma Family Museum of Poles Saving Jews in World War II in Markowa (2016). While these museums tackle similar issues, they differ both in the way they present their narratives and in how they present their exhibits. Examines their reception, Wóycicka asks what the intended message could be according to visitors; she asks whom and what they are supposed to commemorate. This analysis and comparison of entries in the guestbook allow her to demonstrate that despite the thematic overlap their reception is widely different.

\section{Keywords}

Righteous Among the Nations, Polish museums of the "Righteous", guestbooks, research on museum reception, memory of the Holocaust in Poland 